\title{
П.Ф. Литвицкий
}

Первый Московский государственный медицинский университет им. И.М. Сеченова, Российская Федерация

\section{Расстройства липидного обмена}

\section{Contacts:}

Litvitskii Petr Frantsevich, correspondent member of RAMS, PhD, professor, Head of the Department of Pathophysiology of I.M. Sechenov First MSMU Address: 8, Trubetskaya Street, Moscow, RF, 119992, Tel.: (495) 708-34-81

Article received: 26.11.2012, Accepted for publication: 06.12.2012

В лекции приведены современные данные об этиологии, вариантах патогенеза, проявлениях и механизмах развития наиболее распространенных у человека форм патологии липидного обмена: ожирения, истощения, липодистрофий, липидозов, дислипопротеинемий, атеросклероза. Даны материалы для самоконтроля и коррекции уровня усвоения материалов лекции.

Ключевые слова: ожирение, истощение, липодистрофии, дислипопротеинемии, атерогенез, атеросклероз.

(Вопросы современной педиатрии. 2012; 11 (6): 48-62)

Липиды - разнородные по химическому составу вещества. В организме человека они присутствуют в виде жирных кислот, фосфолипидов, холестерина, триглицеридов, стероидов и др. Потребность человека в жирах колеблется в диапазоне 80-100 г в сут.

\section{ТИПОВЫЕ ФОРМЫ НАРУШЕНИЯ ЛИПИДНОГО ОБМЕНА}

K числу наиболее распространенных у человека форм патологии липидного обмена относят ожирение, истощение, липодистрофии, липидозы и дислипопротеинемии (рис. 1).

В зависимости от уровня нарушений метаболизма липидов выделяют расстройства:

- переваривания и всасывания липидов в желудочно-кишечном тракте (например, в результате дефицита липаз поджелудочной железы, нарушения желчеобразования и желчевыделения, расстройств полостного и "мембранного" пищеварения);

- трансмембранного переноса липидов из кишечника в кровь и усвоения их клетками (например, при энтеритах, нарушении кровообращения в стенке тонкого кишечника);

- метаболизма липидов в тканях (например, при дефекте или недостаточности липаз, фосфолипаз, липопротеинлипазы).

В зависимости от клинических проявлений дифференцируют:
- ожирение;

- истощение;

- дислипопротеинемии;

- липодистрофии;

- липидозы.

\section{ОЖИРЕНИЕ}

В норме содержание жировой ткани у мужчин составляет 15-20\% массы тела, у женщин - 20-30\%.

Ожирение - избыточное (патологическое) накопление жира в организме в виде триглицеридов. При этом масса тела увеличивается (в основном за счет жиров) более чем на 20-30\% по сравнению с нормой.

По данным экспертов Всемирной организации здравоохранения, в развитых странах Европы избыточную массу тела имеют от 20 до 60\% населения, в России около $60 \%$.

Ожирение существенно увеличивает риск возникновения ишемической болезни сердца (в 1,5 раза), атеросклероза (в 2 раза), гипертонической болезни (в 3 раза), сахарного диабета (в 4 раза), а также, как допускают, некоторых новообразований (например, рака молочной железы, эндометрия и простаты).

\section{Виды ожирения}

Основные виды ожирения представлены на рис. 2.

В зависимости от степени увеличения массы тела, выделяют 3 степени ожирения в сравнении с т.н. иде-

\section{P.F. Litvitskii}

I.M. Sechenov First Moscow State Medical University, Russian Federation

\section{Disturbances of lipid metabolism}

The article contains modern data on etiology, pathogenesis, manifestations and mechanisms of development of the most common forms of lipid metabolism disturbances in humans, such as obesity, emaciation, lipodystrophy, lipidosis, dyslipoproteinemia and atherosclerosis. The authors give the informative materials for self-testing and correction of the knowledge level. Key words: obesity, emaciation, lipodystrophy, dyslipoproteinemia, atherogenesis, atherosclerosis. 
Рис. 1. Основные формы патологии липидного обмена

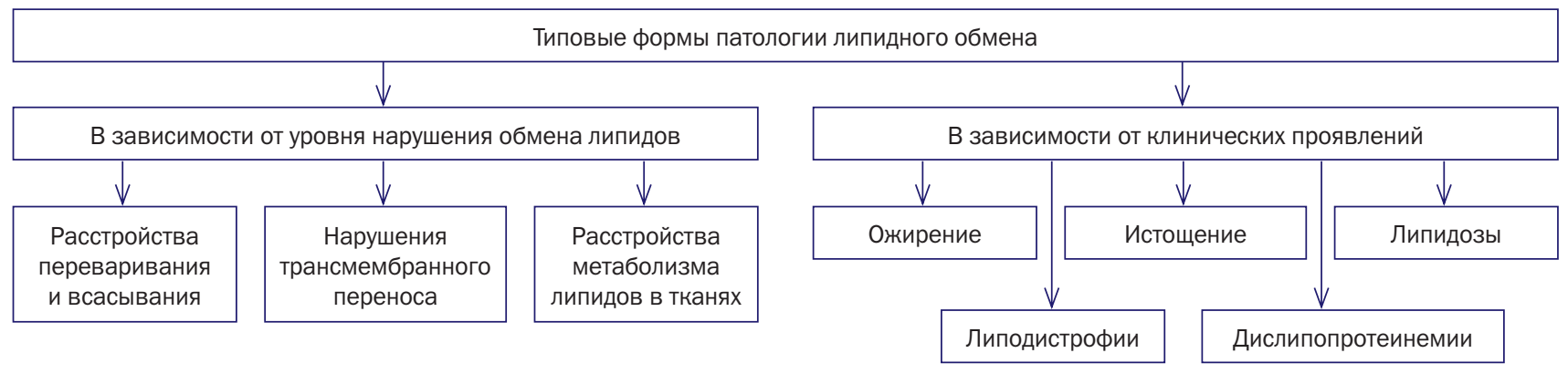

Рис. 2. Виды ожирения

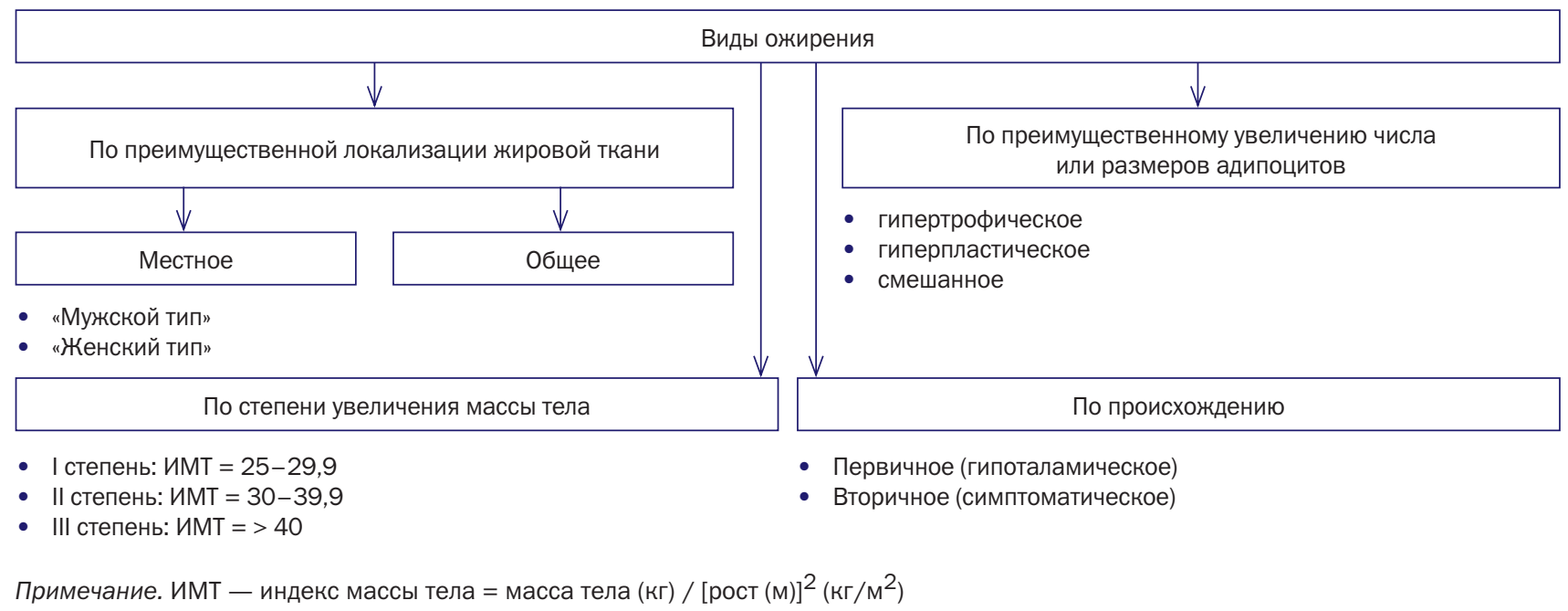

альной массой тела. Для оценки идеальной массы тела используют различные формулы. Наиболее простая из них - индекс Брока. Он рассчитывается путем вычитания из показателя роста (в см) цифры 100.

Кроме того, применяют индекс массы тела (ИМТ):

$$
\text { ИМТ }=\frac{\text { Масса тела (кг) }}{\text { Рост }\left(\mathrm{M}^{2}\right)}\left(\kappa г / \mathrm{M}^{2}\right)
$$

Масса тела считается нормальной при ИМТ в диапазоне 18,5-24,9. Превышение этих значений свидетельствует об избыточной массе тела (табл. 1).

В зависимости от преимущественной локализации жировой ткани различают 2 вида ожирения: общее (равномерное) и местное (локальная липогипертрофия).

Местное ожирение подразделяют на женский, или гиноидный (избыток подкожного жира локализуется преимущественно в области бедер и ягодиц) и мужской тип, или андроидный (при накоплении жира в области живота, спины и грудной клетки; чаще он встречается у мужчин, но нередко развивается и у женщин).

В зависимости от преимущественного увеличения числа или размеров жировых клеток выделяют:

- гиперпластическое ожирение (за счет преимущественного увеличения числа адипоцитов); оно более устойчиво к лечению и в тяжелых случаях требует хирургического вмешательства по удалению избытка жира;

- гипертрофическое (вследствие преимущественного увеличения массы и размеров адипоцитов) - такой вид ожирения чаще наблюдается после 30 лет;

- гиперпластически-гипертрофическое (смешанное).

В зависимости от генеза выделяют первичное и вторичные формы ожирения: первичное (гипоталамическое) ожирение является результатом расстройств системы регуляции жирового обмена (липостата), т.е. самостоятельным заболеванием нейроэндокринного генеза; вторичное (симптоматическое) ожирение - это следствие

Таблица 1. Степени ожирения

\begin{tabular}{|c|c|c|}
\hline имт & Степень & Описательная оценка \\
\hline $18,5-24,9$ & - & Норма \\
\hline $25-29,9$ & I & Повышенная масса тела (“степень зависти окружающих") \\
\hline $30-39,9$ & II & Тучность (“степень улыбки окружающих) \\
\hline$>40$ & III & Болезненная тучность (“степень сочувствия окружающих") \\
\hline
\end{tabular}

Примечание. ИМТ-индекс массы тела. 
либо других форм патологии в организме, обусловливающих снижение энергозатрат (и, следовательно, расхода триглицеридов жировой ткани, например, при гипотиреоидных состояниях или гиподинамии), либо активации синтеза липидов (например, при сахарном диабете или гиперкортицизме).

\section{Причины ожирения}

Причина первичного ожирения - нарушение функционирования системы адипоциты-гипоталамус. Это является результатом дефицита и/или недостаточности эффектов лептина (по подавлению им выработки нейронами гипоталамуса нейропептида Ү, который повышает аппетит и чувство голода).

Причина вторичного ожирения - избыточная калорийность пищи и, как правило, пониженный уровень энергозатрат организма. Энерготраты зависят от степени активности (прежде всего физической) и образа жизни человека. Недостаточная физическая активность является одной из важных причин ожирения.

\section{Патогенез ожирения}

В качестве основных выделяют нейрогенные, эндокринные и метаболические варианты механизма развития ожирения.

\section{Нейрогенные (центрогенный и гипоталамический) \\ варианты патогенеза ожирения (рис. 3) \\ Центрогенный (корковый, психогенный) меха-} низм ожирения - один из (2 других - неврогенная анорексия и булимия) вариантов расстройства пищевого поведения. Причинами включения этого механизма являются различные расстройства психики, характеризующиеся постоянным, иногда непреодолимым стремлением к приему пищи. К числу основных звеньев патогенеза центрогенного ожирения относят:

- активацию серотонин-, дофамин-, опиоидергической и других систем, участвующих в формировании ощущений удовольствия и комфорта;
- восприятие пищи как сильного положительного стимула (допинга), что еще более активирует указанные системы.

Таким образом, замыкается "порочный круг" центрогенного механизма развития ожирения.

Гипоталамический (диэнцефальный, подкорковый) механизм ожирения развивается в результате активации повреждения нейронов вентромедиального и паравентрикулярного ядра гипоталамуса (например, после сотрясения мозга, при энцефалитах, краниофарингиоме, метастазах опухолей в гипоталамус).

Основными звеньями патогенеза гипоталамического ожирения считают следующие.

- Повышение синтеза и секреции нейропептида Ү (без выясненной причины) нейронами заднелатерального вентрального ядра гипоталамуса.

- Прямое повреждение или раздражение нейронов названного выше ядра. Это стимулирует синтез и секрецию нейропептида $Y$ и снижает чувствительность к факторам, ингибирующим синтез нейропептида Y (главным образом, к лептину). Нейропептид Y стимулирует чувство голода и повышает аппетит, а лептин подавляет образование нейропептида $\mathrm{Y}$ как стимулятора аппетита.

- Нарушение участия гипоталамуса в формировании чувства голода. Это чувство формируется при снижении концентрации глюкозы плазмы крови, сокращении мышц желудка при эвакуации пищи и его опорожнении (чувство пищевого дискомфорта - "сосет под ложечкой»). Информация от периферических чувствительных нервных окончаний интегрируется в нервных ядрах гипоталамуса, ответственных за пищевое поведение.

В результате названных выше процессов усиливается выработка нейромедиаторов и нейропептидов, формирующих чувство голода и повышающих аппетит ( $\gamma$-аминомасляной кислоты, дофамина, $\beta$-эндорфина, энкефалинов) и/или нейромедиаторов и нейропептидов, формирующих чувство сытости и угнетающих пищевое

Рис. 3. Нейрогенные механизмы ожирения

\begin{tabular}{|c|c|c|}
\hline \multicolumn{1}{|c|}{ Нейрогенные механизмы ожирения } \\
\hline Центрогенный (корковый, психогенный) \\
Расстройства психики \\
Постоянное непреодолимое стремление к приему пищи \\
$\qquad \begin{array}{c}\text { Прием пищи } \\
\downarrow\end{array}$ \\
Активация систем формирования чувств удовольствия, \\
комфорта \\
$\downarrow$
\end{tabular}


поведение (серотонина, норадреналина, холецистокинина, соматостатина).

\section{Эндокринные варианты ожирения}

К числу наиболее значимых эндокринных механизмов ожирения относят лептиновый, гипотиреоидный, надпочечниковый и инсулиновый (рис. 4).

Лептиновый механизм - ведущий в развитии первичного ожирения. Лептин образуется в жировых клетках. Он снижает аппетит и повышает расход энергии организмом. Уровень лептина в крови прямо коррелирует с количеством белой жировой ткани. Рецепторы к лептину имеют многие клетки, в т.ч. нейроны вентромедиального ядра гипоталамуса. Лептин подавляет образование и выделение гипоталамусом нейропептида Ү. Нейропептид $Y$ формирует чувство голода, повышает аппетит, снижает энергорасходы организма. Между гипоталамусом и жировой тканью существует своего рода отрицательная обратная связь: избыточное потребление пищи, сопровождающееся увеличением массы жировой ткани, приводит к усилению секреции лептина. Это (посредством торможения выработки нейропептида Ү) ослабляет чувство голода. Однако у тучных людей этот регуляторный механизм может быть нарушен, например, из-за повышенной резистентности к лептину или мутации гена лептина.

Контур лептин-нейропептид Y (или липостат) обеспечивает поддержание массы жировой ткани тела липостата (или установочной точки организма в отношении интенсивности энергетического обмена). Помимо лептина, в систему липостата включены инсулин, катехоламины, серотонин, холецистокинин, эндорфины.

Гипотиреоидный механизм ожирения. Он является результатом недостаточности эффектов йодсодержащих гормонов щитовидной железы. Это снижает интенсивность липолиза, скорость обменных процессов в тканях и энергетические затраты организма.

Надпочечниковый (глюкокортикоидный, кортизоловый) механизм ожирения. Его активирует повышенное содержание в сыворотке крови глюкокортикоидов (например, при болезни или синдроме Иценко-Кушинга). Под влиянием избытка глюкокортикоидов активизируется глюконеогенез (в связи с этим развивается гипергликемия), транспорт глюкозы в адипоциты и гликолиз (происходит торможение липолитических реакций и накопление триглицеридов)

Инсулиновый механизм ожирения. Развивается вследствие прямой активации инсулином липогенеза в жировой ткани

Другие эндокринные механизмы ожирения. Ожирение может развиваться также при других эндокринопатиях (например, при дефиците соматотропного и гонадотрофных гормонов).

\section{Метаболические механизмы ожирения}

Эти механизмы связаны в основном с расстройствами обмена углеводов и жиров. Запасы углеводов в организме относительно малы. Они примерно равны их суточному приему с пищей. В связи с этим выработался механизм экономии углеводов.

При повышении в рационе доли жиров скорость окисления углеводов снижается. Об этом свидетельствует соответствующее уменьшение дыхательного коэффициента (отношение скорости образования $\mathrm{CO}_{2}$ к скорости потребления $\mathrm{O}_{2}$ ). Если этого не происходит (при расстройстве механизма ингибирования гликогенолиза в условиях высокой концентрации жиров в крови), активируется механизм, обеспечивающий повышение

Pис. 4. Варианты эндокринного патогенеза ожирения

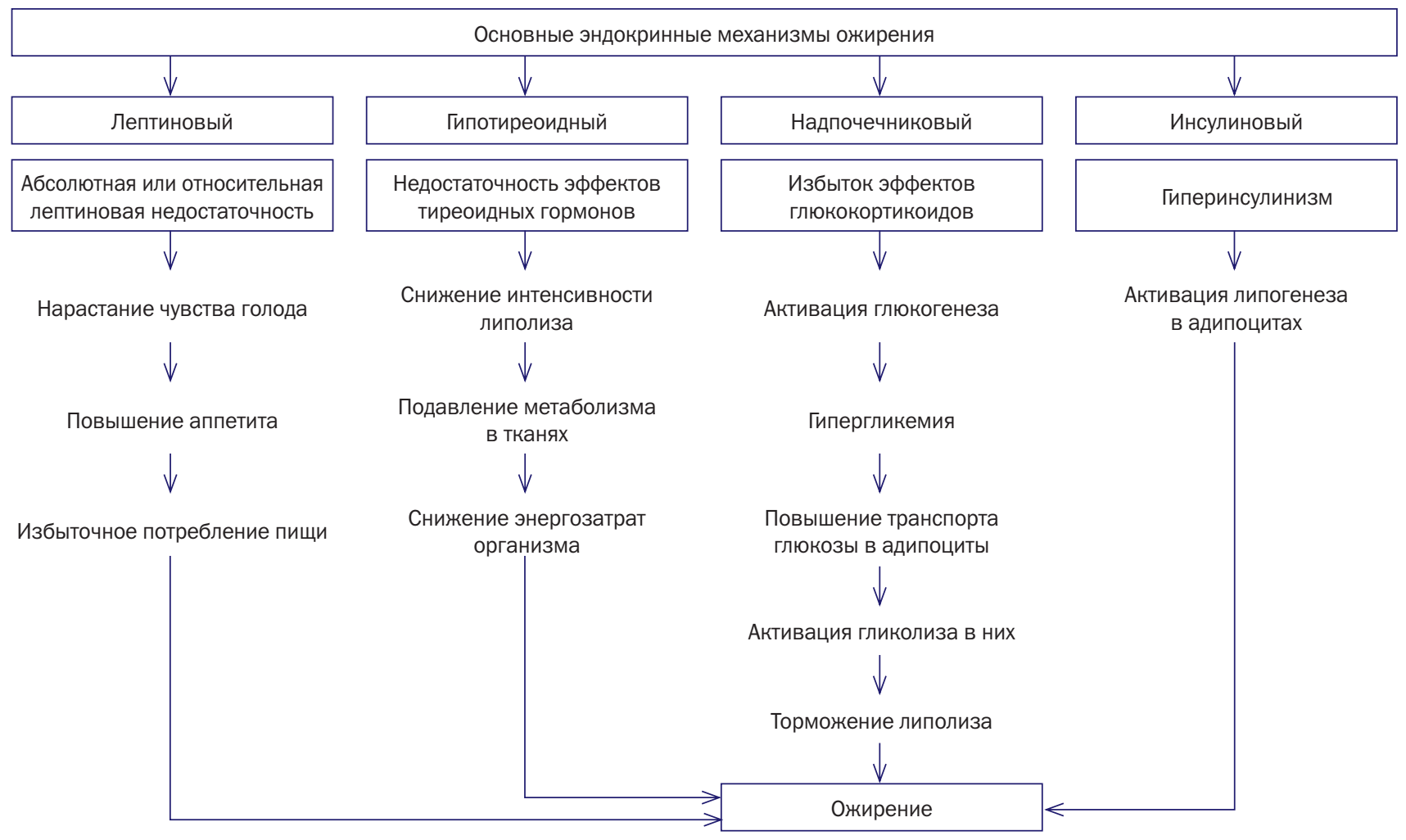


аппетита и увеличение объема приенимаемой пищи, направленное на обеспечение организма необходимым количеством углеводов. В этих условиях жиры накапливаются в виде триглицеридов. Развивается ожирение.

\section{ИСТОЩЕНИЕ}

И истощение, и кахексия характеризуются патологическим снижением массы жировой ткани ниже нормы. Одновременно значительно снижается масса мышечной и соединительной ткани. При истощении дефицит жировой ткани может составлять 20-25\% и более (при ИМТ ниже 20 кг $\left./ \mathrm{M}^{2}\right)$, а при кахексии - более 50\%.

\section{Причины и виды истощения и кахексии}

Различают эндогенные и экзогенные причины истощения.
К экзогенным причинам истощения и кахексии относят вынужденное или осознанное полное либо частичное голодание (в последнем случае - чаще всего с целью похудания). При полном голодании пища в организм не поступает (например, при ее отсутствии, отказе от еды или невозможности приема пищи). При неполном голодании имеет место относительный дефицит пластических веществ и калорий в пище (например, при количественно и качественно неполноценном питании, однородной пище, вегетарианстве), низкая калорийность пищи, не восполняющая энергозатрат организма. Это сопровождается прогрессирующим снижением массы тела.

Эндогенные причины истощения и кахексии подразделяют на первичные и вторичные. Причины первичного (гипоталамического, диэнцефального) истощения приведены на рис. 5, вторичного (симптоматического) на рис. 6.

Рис. 5. Причины первичного истощения и кахексии

Основные причины первичного истощения и кахексии

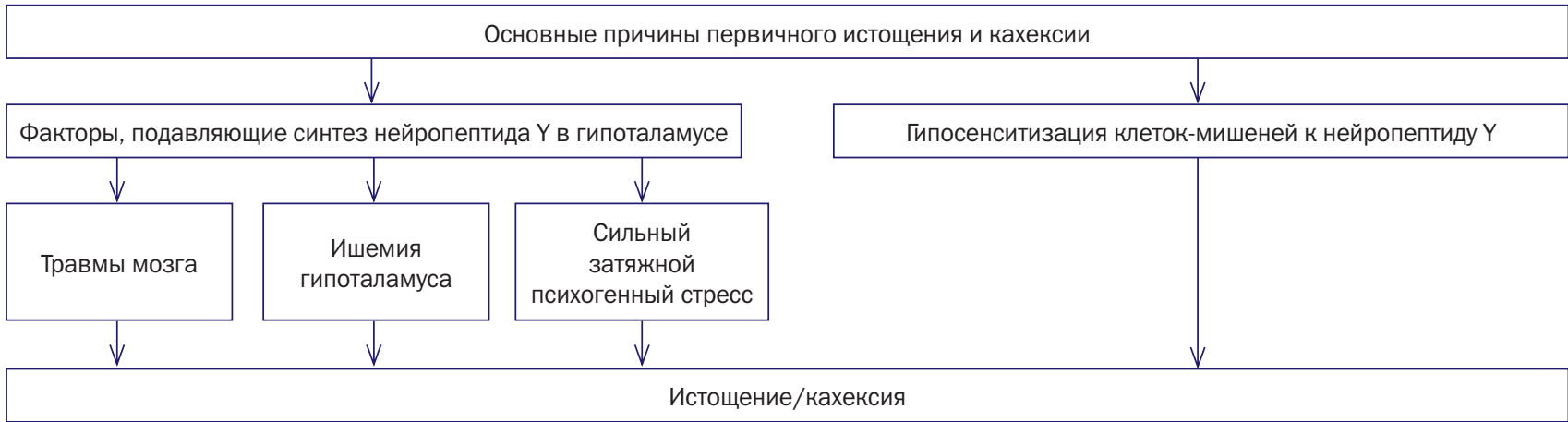

Рис. 6. Причины вторичного истощения и кахексии

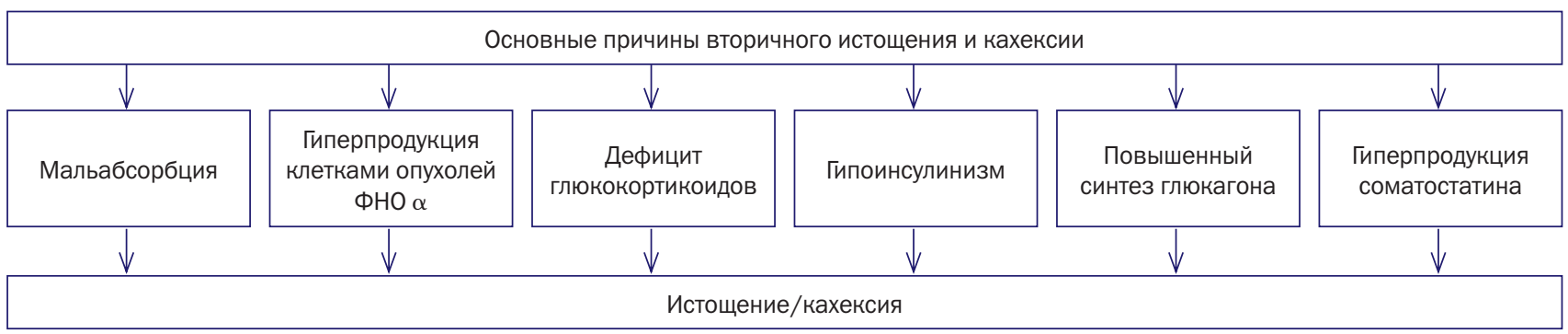

Рис. 7. Основные звенья патогенеза экзогенного истощения и кахексии

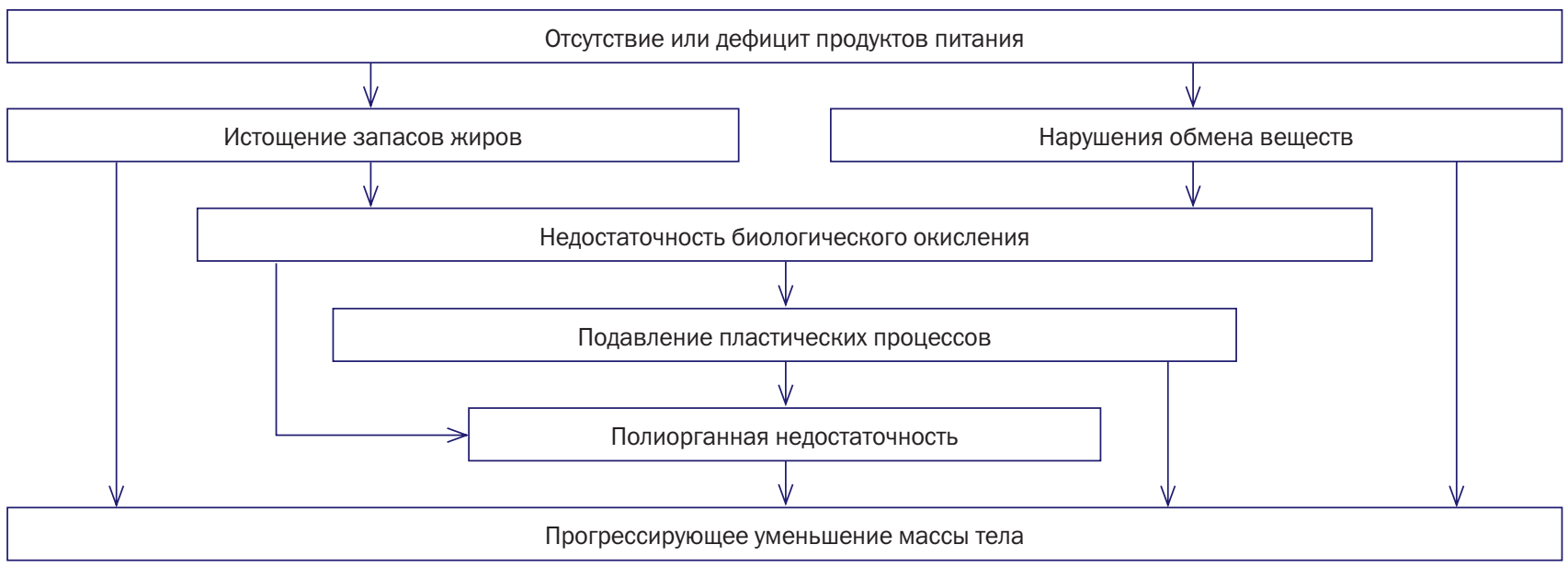


Патогенез экзогенного истощения и кахексии. Отсутствие или значительный дефицит продуктов питания приводят к развитию цепи последовательных и взаимозависимых процессов. Они приведены на рис. 7.

Патогенез эндогенного истощения и кахексии. Механизм развития эндогенного истощения и кахексии различен при их первичных и вторичных (симптоматических) формах.

Первичные эндогенные формы истощения и кахексии имеют 3 основных разновидности: гипоталамическую, кахектиновую и анорексическую.
Патогенез первичной гипоталамической формь (диэнцефальной, подкорковой) истощения и кахексии заключается в снижении или прекращении синтеза и выделения в кровь нейронами гипоталамуса пептида Y. Это приводит к развитию последовательных процессов, приведенных на рис. 8.

Патогенез первичной кахектиновой (цитокиновой) формы истощения и кахексии включает в себя звенья, представленные на рис. 9.

Патогенез анорексической формы истощения и кахексии представлен на рис. 10. У лиц, имеющих

Рис. 8. Основные звенья первичного гипоталамического механизма истощения и кахексии

\begin{tabular}{|c|}
\hline Снижение/прекращение синтеза нейропептида Ү в гипоталамусе \\
\hline Снижение эффективности реакций метаболизма \\
\hline Торможение процесса накопления жира в адипоцитах \\
$\downarrow$ \\
\hline Прогрессирующее уменьшение массы тела \\
\hline
\end{tabular}

Рис. 9. Основные звенья первичного кахектинового механизма истощения и кахексии

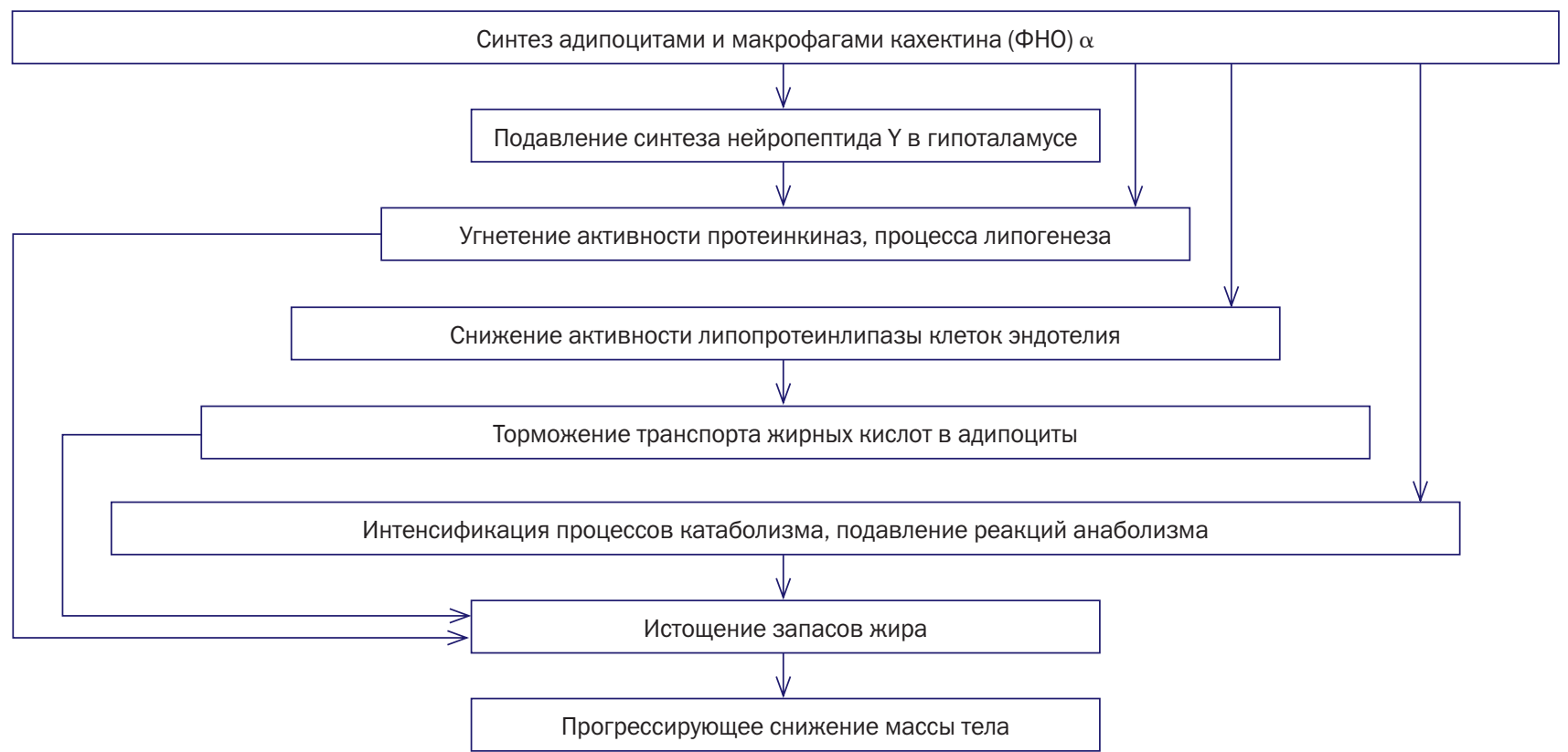

Рис. 10. Патогенез анорексической формы истощения и кахексии

\begin{tabular}{|c|c|c|}
\hline \multicolumn{3}{|c|}{ Повторные, эмоционально негативные стресс-реакции } \\
\hline$\downarrow$ & $\downarrow$ & $\downarrow$ \\
\hline $\begin{array}{c}\text { Избыточная продукция веществ, } \\
\text { подавляющих аппетит (серотонина, } \\
\text { холецистокинина и др.) }\end{array}$ & Повышение продукции кахектина & $\begin{array}{c}\text { Снижение синтеза нейропептида Y } \\
\text { в гипоталамусе }\end{array}$ \\
\hline$\downarrow$ & $\downarrow$ & $\downarrow$ \\
\hline \multicolumn{3}{|c|}{ Анорексия } \\
\hline \multicolumn{3}{|c|}{$\downarrow$} \\
\hline \multicolumn{3}{|c|}{ Прогрессирующее уменьшение массы тела } \\
\hline
\end{tabular}


предрасположенность к развитию анорексии, критическое отношение к своему телу (воспринимаемому как имеющему избыточную массу) вызывает развитие нервно-психических расстройств. Это приводит к длительным эпизодам отказа от приема пищи. Наиболее часто наблюдается у девочекподростков и девушек до 16-18-летнего возраста.

При повторных и эмоционально негативно окрашенных стресс-реакциях имеет место избыточное образование серотонина и холецистокинина, подавляющих аппетит. Дальнейшее течение процесса может привести к реализации эффектов нейропептида Ү и кахектина. Эти факторы и лежат в основе патогенеза нервной анорексии. При затяжном течении процесса развивается выраженное снижение массы тела, вплоть до кахексии.

Вторичные эндогенные формы истощения и кахексии являются важными, нередко главными, симптомами других патологических состояний и болезней (рис. 11).

\section{липодИстРОФИи}

Липодистрофии - состояния, характеризующиеся генерализованной или локальной утратой жировой ткани, реже - избыточным ее накоплением в подкожной клетчатке.

Причины липодистрофий разнообразны и не всегда определяемы. Это может быть широкий спектр факторов: от мутаций разных генов (например, ламинов) до постинъекционных осложнений. Существует большая группа наследственных и врожденных синдромов липодистрофий.

\section{липидозы}

Липидозы - форма нарушения липидного обмена, характеризующаяся расстройствами метаболизма различных видов липидов. К ним относятся, в частности, сфинголипидозы, ганглиозидозы, муколипидозы, адренолейкодистрофии, лейкодистрофии, липофусцинозы, цереброзидозы. Они могут поражать паренхиматозные клетки (паренхиматозные липидозы), жировую клетчатку (ожирение, истощение) или стенки артериальных сосудов (атеро- и артериосклероз).

\section{ДИСЛИПОПРОТЕИНЕМИИ}

Дислипопротеинемии - состояния, связанные с отклонением от нормы содержания, структуры и соотношения в крови различных липопротеинов (ЛП).

Нарушения метаболизма ЛП - главное звено патогенеза атеросклероза, ишемической болезни сердца, панкреатита и других заболеваний.

Характер течения и клинические проявления дислипопротеинемий определяются несколькими факторами:
- наследуемыми свойствами организма (например, составом, соотношением и уровнем различных ЛП, особенностями их метаболизма);

- действием агентов внешней среды (к примеру, набором продуктов питания, особенностями рациона и режима приема пищи);

- наличием или отсутствием сопутствующих заболеваний (ожирения, гипотиреоза, сахарного диабета, поражений почек и печени).

\section{Характеристика липопротеинов}

В плазме крови циркулируют различные липиды. Свободные жирные кислоты переносятся альбуминами, а триглицериды, холестерин, эфиры холестерина и фосфолипиды, небольшое количество жирных кислот транспортируются в составе ЛП. Эти сферические частицы состоят из гидрофобной сердцевины (содержит эфиры холестерина и триглицериды) и гидрофильной оболочки (содержит холестерин, фосфолипиды и аполипопротеины). Основные характеристики разных ЛП приведены в табл. 2.

Аполипопротеины обеспечивают сохранение упорядоченной структуры мицелл лП, взаимодействие лП с рецепторами клеток, обмен компонентами между ЛП.

\section{Атерогенность липопротеинов}

ЛП подразделяют на а- и антиатерогенные (рис. 12).

Антиатерогенный эффект ЛП высокой плотности (ЛПВП) определяется следующими их свойствами: способностью удалять избыток холестерина из плазматической мембраны клеток, включая эндотелий сосудов, и переносить его в печень, где холестерин удаляется с желчью; более высоким сродством ЛПВП к апоЛП Е- и апоЛП В-рецепторам по сравнению с ЛП низкой плотности (ЛПНП). Это определяется высоким содержанием аполП Е в ЛПВП. В результате лПВП препятствуют захвату клетками частиц, насыщенных холестерином.

Оценка потенциальной атерогенности ЛП крови проводится путем расчета холестеринового коэффициента атерогенности:

$$
\frac{\text { холестерин общий - холестерин ЛПВП }}{\text { холестерин ЛПВП }}
$$

В норме холестериновый коэффициент атерогенности не превышает 3,0. При увеличении этого значения риск развития атеросклероза возрастает.

Рис. 11. Основные причины вторичного эндогенного истощения и кахексии

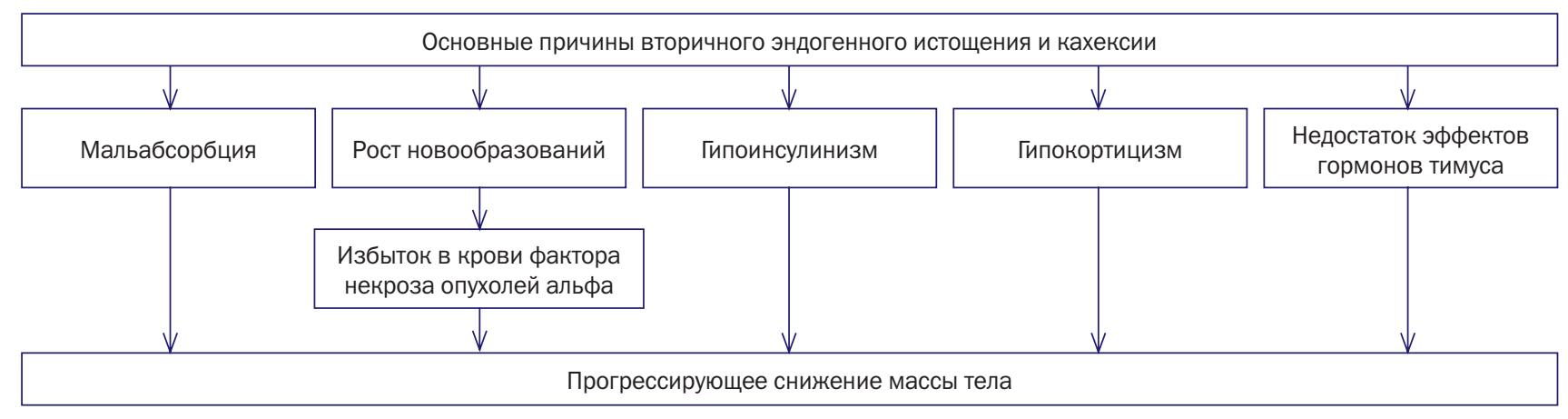


Таблица 2. Виды и основные свойства липопротеинов

\begin{tabular}{|c|c|c|c|c|c|}
\hline Свойства & Хиломикроны & лпонп & лппп & лпнп & лпвп \\
\hline Размер частиц, нм & $75-1200$ & $40-70$ & $25-35$ & $22-28$ & $5-12$ \\
\hline Плотность, г/см 3 & $<0,98$ & $0,98-1,006$ & $1,006-1,019$ & $1,019-1,063$ & $1,063-1,210$ \\
\hline \multicolumn{6}{|l|}{ Состав, \%: } \\
\hline Холестерин & $3-7$ & $20-30$ & $30-50$ & $51-58$ & $18-25$ \\
\hline Триглицериды & $80-95$ & $50-65$ & $30-40$ & $4-10$ & $3-7$ \\
\hline Фосфолипиды & $3-6$ & $15-20$ & $20-25$ & $18-24$ & $24-32$ \\
\hline Белок & $1-2$ & $6-10$ & $10-15$ & $18-22$ & $45-55$ \\
\hline АполП & $\begin{array}{l}\text { B48,Al, All, AIV, Cl, } \\
\text { CII, CIII, E }\end{array}$ & $\mathrm{B} 100, \mathrm{Cl}, \mathrm{ClI}, \mathrm{CIII}, \mathrm{E}$ & B100, E & B100 & $\begin{array}{c}\text { Al, All, AIV, Cl, CII, } \\
\text { CIII, E }\end{array}$ \\
\hline Источник & $\begin{array}{l}\text { Тонкая кишка, } \\
\text { липиды пищи }\end{array}$ & $\begin{array}{c}\text { Печень, тонкая } \\
\text { кишка }\end{array}$ & лпонП & лпонп, лПпп & $\begin{array}{c}\text { Тонкая кишка, } \\
\text { печень }\end{array}$ \\
\hline Атерогенность & Не доказана & Не доказана & Да & Высокая & Антиатерогенны \\
\hline
\end{tabular}

Примечание. лпонП - липопротеины очень низкой плотности, лпПП - липопротеины промежуточной плотности,

лПНП - липопротеины низкой плотности, лПВП - липопротеины высокой плотности, апоЛП - аполипопротеины.

Рис. 12. Виды липопротеинов в зависимости от их атерогенности

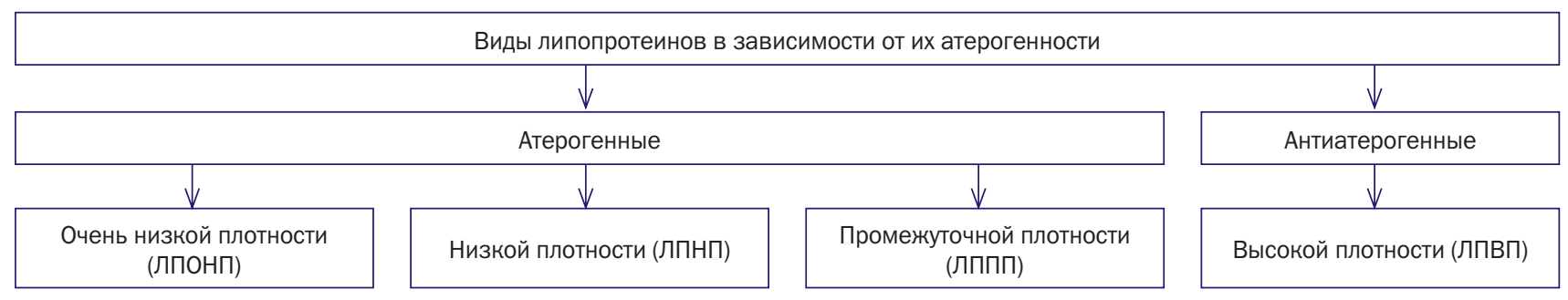

Таблица 3. Наиболее часто встречающиеся патологические процессы, приводящие к развитию вторичных дислипопротеинемий

\begin{tabular}{|c|c|c|}
\hline Заболевание & Тип & Механизм развития \\
\hline Сахарный диабет & I, IV, V & $\begin{array}{c}\text { Снижение активности ЛПЛазы, избыточный приток жирных } \\
\text { кислот в печень, усиление синтеза лпонП }\end{array}$ \\
\hline Гепатит & II & Нарушение секреции липидов \\
\hline Первичный цирроз печени & II & Нарушение синтеза лп \\
\hline Нефротический синдром & II, IV, V & Повышенное образование лП и триглицеридов \\
\hline Гипотиреоз & II, IV & Пониженный катаболизм липидов \\
\hline Гипофизарная недостаточность & IV & Пониженный катаболизм липидов \\
\hline Хронический алкоголизм & IV, V & Снижение активности ЛПЛазы, повышенный синтез ЛП \\
\hline
\end{tabular}

Примечание. лпЛаза - липопротеинлипаза, лп - липопротеины, лпонП — липопротеины очень низкой плотности.

\section{Виды дислипопротеинемий}

Более 30\% первичных дислипопротеинемий являются наследуемыми формами патологии (как моно-, так и полигенные с многофакторным генезом). Около 70\% дислипопротеинемий считаются приобретенными. Вторичные (приобретенные) дислипопротеинемии представляют собой симптомы других болезней. Они сопровождают многие заболевания человека (табл. 3).

Различные наследственные дефекты, а также приобретенные патологические процессы и болезни часто приводят к сходным изменениям содержания и профиля различных ЛП. В связи с этим требуется тонкая диффе- ренцировка их происхождения, позволяющая проводить эффективное лечение.

\section{Гиперлипопротеинемии}

Это состояния, характеризующиеся расстройством образования, транспорта и обмена ЛП и проявляющиеся стойким повышением в плазме крови содержания холестерина и/или триглицеридов.

\section{Типы гиперлипопротеинемий}

В 1967 г. Фредриксон и соавт. разработали классификацию гиперлипопротеинемий (гиперлипидемий). 
В основу были положены данные о содержании общего холестерина и триглицеридов в плазме крови, а также особенности распределения фракций лп при их электрофорезе и ультрацентрифугировании. На этом основании было выделено 5 типов гиперлипопротеинемий. Позднее эта классификация была пересмотрена специалистами Всемирной организации здравоохранения (табл. 4).

\section{Комбинированные дислипопротеинемии}

Комбинированные дислипопротеинемии характеризуются нарушением соотношения различных фракций ЛП.

\section{Атеросклероз}

Атеросклероз - это прогрессирующее накопление избытка липопротеинов и других компонентов крови, сопровождающееся реактивным образованием фиброзной ткани преимущественно во внутренней оболочке артерий эластического и мышечно-эластического типа, а также комплексом других изменений в них.

В результате атеросклеротического поражения сужается просвет артерий, нарушается кровоснабжение органов и тканей, развиваются осложнения в виде кальциноза и аневризм стенок сосудов, тромбоза, эмболий и др.

Наиболее поражаемые атеросклерозом регионы сосудистого русла: брюшной отдел аорты, коронарные артерии, сонные артерии, артерии мозга, почечные артерии, артерии брыжейки и нижних конечностей.

Первые признаки начинающегося атерогенеза обнаруживаются уже у детей 9-10 лет. К 25 годам они выявляются (в виде липидных полосок) на 30-50\% поверхности аорты. В 10-15-летнем возрасте липидные полоски формируются в коронарных артериях, а у большинства 30-40-летних людей их можно обнаружить в сосудах мозга. В процессе прогрессирования атеросклероза раз- виваются фиброзные бляшки, происходит их кальцификация, изъязвление и прочие изменения.

Атеросклероз является разновидностью артериосклероза - его атероматозной формой (рис. 13).

\section{Факторы риска развития атеросклероза}

Известно не менее 250 факторов, способных стать причиной и/или условиями, способствующими возникновению и развитию атеросклероза. В связи с трудностью четкого разграничения различных патогенных факторов на причины и условия, их обозначают как факторы риска.

К наиболее значимым факторам риска относят курение, сахарный диабет, артериальную гипертензию, ожирение, гиперхолестеринемию (отношение ЛПНП к ЛПВП более 5:1), гипертриглицеридемию, гиподинамию, инсульты и заболевания сердечно-сосудистой системы в семейном анамнезе, прием пероральных контрацептивов.

\section{Патогенез атеросклероза}

К настоящему времени сложилось несколько концепций о патогенезе атеросклероза. Между ними имеются существенные отличия, но больше общих черт. Далее приводится характеристика общих звеньев патогенеза атеросклероза, имеющих наибольшее фактическое подтверждение и важное клиническое значение.

Выделяют следующие этапы атерогенеза:

- инициация;

- прогрессирование атерогенеза;

- формирование атеромы;

- образование фиброатеромы;

- развитие осложнений атеросклероза.

Инициация атерогенеза

Этап инициации атерогенеза (рис. 14) заключается в повреждении и активации эндотелиальных клеток и экспрессии молекул адгезии на их поверхности. Этот

Таблица 4. Типы гиперлипопротеинемий и содержание различных видов липопротеинов при них

\begin{tabular}{|c|c|c|c|c|c|}
\hline Тип & Хиломикроны & окх & лпонп & лппп & лпнп \\
\hline 1 & $\uparrow$ & $\mathrm{N}$ & $\mathrm{N}$ & $\mathrm{N}$ & $\mathrm{N}$ \\
\hline IIA & $\mathrm{N}$ & $\mathrm{N}$ & N & $\mathrm{N}$ & $\uparrow$ \\
\hline IIB & $\mathrm{N}$ & $\mathrm{N}$ & $\uparrow$ & $\mathrm{N}$ & $\uparrow$ \\
\hline III & $\mathrm{N}$ & $\uparrow$ & N & $\uparrow$ & $\mathrm{N}$ \\
\hline IV & $\mathrm{N}$ & $\mathrm{N}$ & $\uparrow$ & N & $\mathrm{N}$ \\
\hline V & $\uparrow$ & $\mathrm{N}$ & $\uparrow$ & N & $\mathrm{N}$ \\
\hline
\end{tabular}

Примечание. N - норма, $\uparrow$ - повышение, ОКХ - остаточные компоненты хиломикронов, ЛПоНП — липопротеины очень низкой плотности, лпПп — липопротеины промежуточной плотности, лпнП — липопротеины низкой плотности.

Рис. 13. Формы артериосклероза

\begin{tabular}{|c|c|c|}
\hline \multicolumn{3}{|c|}{ Формы артериосклероза } \\
\hline$\downarrow$ & \multicolumn{2}{|c|}{$\downarrow$} \\
\hline \multirow{2}{*}{$\begin{array}{c}\text { Атероматозная (син.: атеросклероз) - } \\
\text { поражение артерий эластического } \\
\text { и мышечно-эластического типа }\end{array}$} & \multicolumn{2}{|c|}{ Неатероматозные } \\
\hline & $\downarrow$ & $\downarrow$ \\
\hline & $\begin{array}{c}\text { Локальная кальцификация стенок } \\
\text { артерий мышечного типа }\end{array}$ & $\begin{array}{c}\text { Артериолосклероз - дегенерация, } \\
\text { гиалиноз, склероз стенок артериол } \\
\text { и мелких артерий }\end{array}$ \\
\hline
\end{tabular}


Рис. 14. Основные звенья атерогенеза: этап инициации

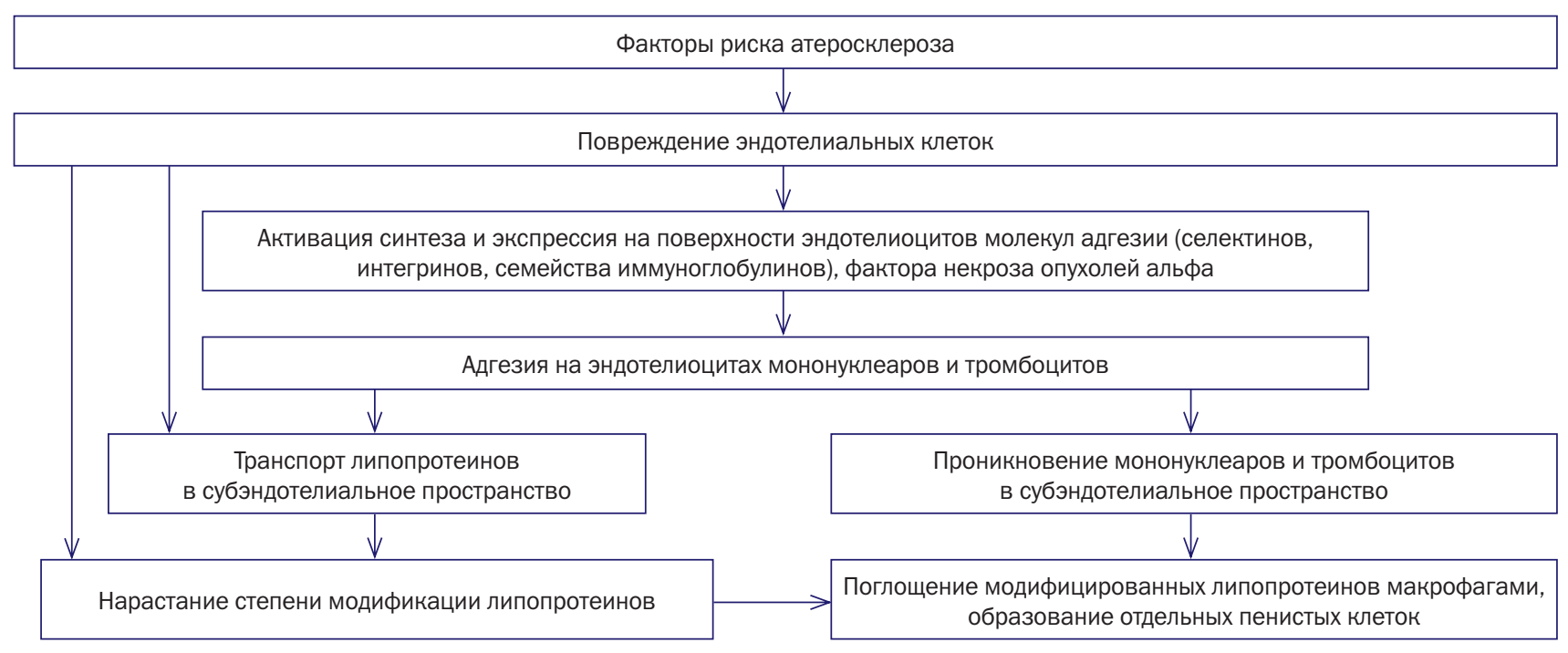

этап носит неспецифический характер. Его признаки могут быть обнаружены уже на 8-10-м году жизни.

Наиболее вероятными причинами инициации атеросклероза являются:

- иммунопатологические реакции, протекающие с поражением эндотелиоцитов;

- гипоксия различного происхождения;

- эндотоксинемии (инфекционные и неинфекционные, например, при вирусных инфекциях, микробных интоксикациях, пищевых отравлениях, шоке, коме);

- гомоцистеинемия;

- дислипопротеинемии (наследственные, врожденные, приобретенные);

- значительные перепады артериального давления и/или скорости кровотока (последнее имеет наибольшее значение в местах изменения диаметра артерий, их ветвлений и изгибов);

- раннее начало курения.

Основные звенья патогенеза атеросклероза

- Активация синтеза и выделения на поверхность эндотелиоцитов молекул адгезии (селектинов Р и E, ICAM1, ICAM2, VCAM, интегринов и др.), а также кахексина. Это обусловливает адгезию на поверхности эндотелиоцитов мононуклеарных клеток (в основном, моноцитов), а также тромбоцитов; проникновение моноцитов и тромбоцитов в субэндотелиальное пространство.

- Транспорт в субэндотелиальное пространство ЛП крови. В субэндотелии ЛП взаимодействуют с молекулами гликозаминогликанов. Находящиеся в интерстиции ЛП, особенно связанные с макромолекулами матрикса, подвергаются дальнейшим изменениям (окислению, ацетилированию, восстановлению, образованию перекисей, альдегидов и пр.). Особую роль в модификации ЛП играет свободнорадикальное перекисное окисление липидов. Об этом свидетельствуют следующие факты. В аорте и других артериях человека обнаружены липооксигеназы (ферменты, катализирующие образование перекисей липидов). При распаде перекисей липидов накапливаются свободные радикалы, способные неэнзиматически инициировать свободнорадикальное перекисное окис- ление липидов. В стенке сосуда ЛП изолированы от антиоксидантных факторов плазмы крови (аскорбиновой кислоты, уратов, сульфгидрильных групп белков), поэтому особенно подвержены модификации в ходе свободнорадикального перекисного окисления липидов. Окисляться может не только липидная, но и белковая часть ЛП (апоЛП), необходимая для взаимодействия с рецепторами ЛП.

- Модифицированные липиды служат хемоаттрактантами для лейкоцитов, а также подвергаются фагоцитозу макрофагами. Макрофаги с большим количеством ЛП в цитоплазме получили название пенистых клеток. Такое название связано с тем, что при обработке срезов ткани из макрофагов вымываются липиды. Под микроскопом вакуоли, образовавшиеся после удаления липидов, напоминают пену.

\section{Прогрессирование атерогенеза}

Этапы прогрессирования атерогенеза представлены на рис. 15.

Патогенез этапа прогрессирования атеросклероза включает следующие ключевые звенья: миграцию в участки интимы артерий с поврежденными и активированными эндотелиальными клетками большого числа моноцитов и тромбоцитов; активацию синтеза лейкоцитами, тромбоцитами, эндотелиоцитами различных биологически-активных веществ (факторов хемотаксиса, кининов, простагландинов, факторов роста, факторов некроза опухолей), а также образование активных форм кислорода и липопероксидов. Указанные факторы потенцируют повреждение эндотелия и подэндотелиального слоя артерий. Описанные выше механизмы и изменения интимы обозначают как этап начального повреждения артерии, дисфункции эндотелия. Последующие изменения в стенке артерий относятся к этапу липидных пятен и полосок. Это усиление поглощения макрофагами (мигрировавшими в интиму моноцитами) модифицированных ЛП при помощи Т.н. скавенджер-рецепторов (от англ. "Scavenger receptor»). Скавенджер-рецепторь макрофагов связываются преимущественно с модифицированными ЛПнП. Далее происходит превращение макрофагов, насыщенных липидами (в основном, эфи- 
Рис. 15. Основные звенья патогенеза атеросклероза: этап прогрессирования атерогенеза

\begin{tabular}{|c|c|}
\hline \multicolumn{2}{|c|}{ Миграция в зону повреждения интимы большого числа моноцитов и тромбоцитов } \\
\hline \multicolumn{2}{|c|}{$\downarrow$} \\
\hline \multicolumn{2}{|c|}{$\begin{array}{c}\text { Активация образования ими факторов хемотаксиса, роста, некроза опухолей, а также кининов, простагландинов, активных форм } \\
\text { кислорода, липопероксидов }\end{array}$} \\
\hline \multicolumn{2}{|c|}{$\downarrow$} \\
\hline \multicolumn{2}{|c|}{ Потенцирование повреждения эндотелиоцитов и субэндотелиального слоя, транспорта в интиму и модификации липопротеинов } \\
\hline \multicolumn{2}{|l|}{ (- } \\
\hline \multicolumn{2}{|c|}{ Нарастание поглощения макрофагами модифицированных липопротеинов (в основном лпнп) } \\
\hline \multicolumn{2}{|c|}{$\downarrow$} \\
\hline \multicolumn{2}{|c|}{ Миграция в зону повреждения интимы гладкомышечных клеток, их пролиферация и трансформация в макрофагоподобные клетки } \\
\hline \multicolumn{2}{|c|}{$\downarrow$} \\
\hline \multicolumn{2}{|c|}{ Формирование липидных пятен и полосок } \\
\hline \multicolumn{2}{|c|}{$\downarrow$} \\
\hline \multicolumn{2}{|c|}{ Нарастание миграции, пролиферации и трансформации гладкомышечных клеток в макрофагоподобные } \\
\hline$\downarrow$ & $\downarrow$ \\
\hline Поглощение ими большого количества липопротеинов & $\begin{array}{c}\text { Синтез ими компонентов межклеточного вещества (эластина, } \\
\text { коллагена, протеогликанов и др.) }\end{array}$ \\
\hline \multicolumn{2}{|l|}{$\downarrow$} \\
\hline \multicolumn{2}{|c|}{ Формирование атером и фиброатером } \\
\hline \multicolumn{2}{|c|}{$\downarrow$} \\
\hline \multicolumn{2}{|c|}{ Сужение просвета артерий } \\
\hline
\end{tabular}

рами холестерина), в пенистые клетки, затем миграция из средней оболочки артерий в зону повреждения интимы гладкомышечных клеток, их пролиферация и синтез ими биологически активных веществ. Полагают, что существует 2 фенотипа гладкомышечных клеток сосудистой стенки: сократительный и синтетический. Сократительный фенотип имеет многочисленные миофиламенты и отвечает на воздействие вазоконстрикторов и вазодилататоров. Подобные гладкомышечные клетки не способны к миграции и не вступают в митозы, т. к. нечувствительны к эффектам факторов роста. Синтетический фенотип синтезирует компоненты межклеточного вещества (коллаген, эластин, протеогликан), цитокины и факторы роста. Гладкомышечные клетки в области атеросклеротического поражения сосудистой стенки перепрограммируются с сократительного на синтетический фенотип. При атеросклерозе они вырабатывают факторы роста (например, тромбоцитарный фактор роста PDGF, щелочной фактор роста фибробластов bFGF), усиливающие пролиферацию соседних гладкомышечных клеток. Механизм регуляции фенотипа гладкомышечных клеток хорошо описан. Показано, что эндотелий вырабатывает и секретирует гепариноподобные вещества, поддерживающие сократительный фенотип гладкомышечных клеток. Факторы паракринной регуляции, продуцируемые эндотелиальными клетками, контролируют тонус сосудов. Среди них: производные арахидоновой кислоты (простагландины, лейкотриены и тромбоксаны), эндотелин-1, моноооксид азота (NO) и др. Недостаточность NO вызывает повышение артериального давления, образование атеросклеротических бляшек; избыток NO может привести к коллапсу.

\section{Переходный этап атерогенеза}

Этот этап атерогенеза - липосклеротический характеризуется нарастанием процессов поступления ЛП в интиму, их модификацией, образованием и распадом пенистых клеток. Это приводит к значительному увеличению содержания в интерстициальном пространстве модифицированных ЛП и компонентов соединительной ткани. Описанные выше этапы атерогенеза, включая переходный, клинически могут не проявляться.

Формирование атеромы и фиброатеромы обусловлено 3 основными факторами:

- массированным проникновением моноцитов крови в интиму артерии;

- увеличением масштаба миграции из средней оболочки сосуда гладкомышечных клеток, их пролиферации и приобретение ими синтетического фенотипа (трансформация);

- прогрессирующей активацией синтеза компонентов межклеточного вещества соединительной ткани (протео- и гликозаминогликанов, коллагеновых и эластических волокон).

Причинами указанных изменений являются:

- продолжающееся действие факторов риска;

- формирование и/или активация по ходу атерогенеза факторов, потенцирующих повреждение стенки артерии (например, свободных радикалов, липопероксидов, факторов некроза опухолей, аутоагрессивных иммуноглобулинов и лимфоцитов);

- эффекты цитокинов (увеличение интенсивности миграции моноцитов в интиму);

- стимуляция таксиса, пролиферации и трансформации гладкомышечных клеток; 
Рис. 16. Основные звенья патогенеза атеросклероза: этап развития осложнений атеросклероза

Модификация атером и фиброатером:
Кальцификация их
Образование трещин и изъязвление крышки фиброатером, формирование пристеночных и интрамуральных тромбов
Разрыв стенок новообразованных микрососудов
Кровоизияние в стенку артерии

- усиление захвата макрофагами ЛП;

- активация синтеза гладкомышечных клеток компонентов межклеточного вещества и началом формирования фиброзной крышки атеромы).

Сформировавшаяся атерома характеризуется:

- наличием значительного числа клеточных элементов (пенистых клеток, гладкомышечных клеток на разных этапах пролиферации и трансформации, лимфоцитов, гранулоцитов, тромбоцитов);

- массивными скоплениями внеклеточных лп, формирующих ядро атеромы.

Фиброатерома, в дополнение к свойствам атеромы, характеризуется формированием фиброзной крышки над липидным ядром и развитием сети микрососудов, окружающих атеросклеротический очаг.

Атеромы (и особенно фиброатеромы) выступают в просвет артерии, уменьшают его, а также стимулируют тромбообразование.

Развитие осложнений атеросклероза

Этап развития осложнений атеросклероза представлен на рис. 16.

Дальнейшая модификация атером (особенно фиброатером) приводит к накоплению в них кальция и его соединений (в особенности в крышке фиброатеромы). Этот процесс получил название "кальцификация", “атерокальциноз". Далее образуются трещины крышки фиброатеромы и/или ее изъязвления. Трещина крышки фиброатеромы может сопровождаться высвобождением содержимого атеромы в просвет артерии и образованием пристеночного тромба (с угрозой обтурации артерии) и/или эмболии. Происходит разрыв стенок новообразованных микрососудов по периметру атеромы или фиброатеромы. Это может обусловить кровоизлияние в стенку артерии и/или образование пристеночных и интрамуральных тромбов.

К наиболее частым и значимым клиническим осложнениям атеросклероза относят:

- инфаркты органов (сердца, мозга, почки, легких и др.);

\section{REFERENCES}

1. Litvitskii P. F. Patofiziologiya. Klinicheskaya patofiziologiya. T. 1. Glava 10 [Pathophysiology. Clinical Pathophysiology. Volume 1. Chapter 10]. Moscow, GEOTAR-Media, 2012. pp. 282-301.
- кровоизлияния и кровотечения;

- ишемию органов и тканей (включая ишемическую болезнь сердца, ишемический инсульт, ишемиюпочек, стенки кишечника и конечностей).

Ишемия органов развивается вследствие сужения просвета артерии (атеромой, фиброатеромой, пристеночным тромбом, эмболом), а также сокращения гладкомышечных клеток артериол (под влиянием сосудосуживающих веществ, выделяемых клетками в области атеросклеротических изменений, - лейкотриенов, эндотелина, тромбоксана $\mathrm{A}_{2}$, вазоконстрикторных простагландинов).

\section{Принципы профилактики и терапии атеросклероза}

Этиотропный принцип имеет целью исключение или уменьшение степени выраженности атерогенного действия факторов риска, особенно у лиц с высокой вероятностью развития атеросклероза (на основе анализа возможных факторов риска у конкретного пациента). Примером могут служить применение гиполипидемических лекарственных средств, соблюдение диеты, отказ от курения.

Патогенетический принцип терапии и профилактики атеросклероза направлен на разрыв цепочки атерогенеза. Примерами таких воздействий может быть применение антиагрегантов, антикоагулянтов и фибринолитических средств (уменьшающих степень агрегации форменных элементов крови и угрозу тромбообразования на поверхности атеромы и фиброатеромы), а также лекарственных препаратов, тормозящих внутриорганное (внутриклеточное) образование холестерина и его производных (к примеру, статинов - ловастатина, симвастатина и др.).

Симптоматический принцип лечения при атеросклерозе преследует цель устранения и/или уменьшения степени выраженности симптомов атеросклероза, в особенности имеющих тягостный, неприятный характер, или чреватых ишемией и некрозом тканей (например, эпизодов головной боли, стенокардии, болей в различных органах, конечностях и др.).
2. Gould B. Pathophysiology for the health profession. 3rd ed. Elsevier. 2006. P. 208, 318-322, 349.

3. McCance K., Huenter S. Pathophysiology. The biologic basis for disease in adults and children. 5th Ed. Elsevier. 2006. P. 916, 1081-1086, 1100-1105. 


\section{ТЕСТОВЫЕ ЗАДАНИЯ ПО ТЕМЕ «НАРУШЕНИЯ ЛИПИДНОГО ОБМЕНА. АТЕРОСКЛЕРОЗ"}

1. Всасывание липидов в тонком кишечнике может нарушаться: (4)

1) при желчнокаменной болезни

2) недостаточном выделении с панкреатическим соком липазы и фосфолипазы

3) недостаточной выработке липокаина в поджелудочной железе

4) поражении эпителия тонкого кишечника

5) нарушении фосфорилирования глицерина в энтероцитах

6) недостаточном образовании триглицеридлипазы в адипоцитах

2. Верно то, что: (2)

1) ЛП - комплекс белков и липидов, связанных нековалентными связями

2) ЛП отдельных классов характеризуются постоянным составом и обычно не обмениваются между собой белками и липидами

3) ЛП образуются многими клетками периферических тканей, включая жировую ткань

4) ЛП состоят из гидрофобного ядра и гидрофильной оболочки

3. Для ЛПвП характерны следующие свойства: (4)

1) высокое относительное содержание белков

2) высокое относительное содержание триглицеридов

3) основной белковый компонент - апоЛП В

4) антиатерогенная активность

5) основной белковый компонент - аполп А

6) образуются в печени

7) образуются в циркулирующей крови

4. Гиперлипопротеинемии вызывают: (4)

1) патология рецепторов ЛПнП

2) недостаточная активность триглицеридлипазы адипоцитов

3) мутации гена, кодирующего апоЛП Е

4) снижение активности липопротеинлипазы плазмы крови

5) повышенное образование липокаина клетками поджелудочной железы

6) избыточное выделение в кровь глюкагона

7) печеночная недостаточность с выраженной холемией

8) мутация гена, кодирующего апоЛП А, В, при которой апобелки не синтезируются

5. Гиполипопротеинемия может быть вызвана следующими причинами: (3)

1) мутациями гена, кодирующего апоЛП А

2) снижением активности липопротеинлипазы плазмы крови

3) мутациями гена, кодирующего апоЛп В

4) поражением печени с развитием печеночной недостаточности

5) дефицитом образования тиреоидных гормонов

6) диетой, обедненной жирами

6. Врожденная недостаточность липопротеинлипазы характеризуется: (4)

1) нарушением превращения хиломикронов в ремнантные частицы

2) нарушением превращения ЛПОНП в остаточные частицы

3) гиперлипидемией

4) гиполипидемией
5) нарушением перехода лпВП в лПнП

6) нарушением перехода ЛПОНП в ЛПНП

7) резкой активацией атерогенеза

7. По механизмам развития выделяют следующие формы ожирения: (3)

1) алиментарное

2) эндокринное

3) гиподинамическое

4) церебральное

5) дистрофическое

6) гиперлипидемическое

8. Негативные последствия ожирения заключаются: (3)

1) в ускорении атерогенеза

2) нарушении пищеварения

3) повышенном риске возникновения сахарного диабета

4) повышенном риске развития гипертонической болезни

5) жировой дистрофии печени

6) слабости скелетной мускулатуры

9. Ожирение развивается: (3)

1) при синдроме Иценко-Кушинга

2) микседеме

3) гипертиреозе

4) альдостеронизме

5) дефиците липотропного гормона гипофиза

10. Причинами модификации ЛП являются: (5)

1) гликозилирование

2) образование антител к аполп

3) активация свободнорадикального перекисного окисления липидов

4) образование комплекса с гликозаминогликанами межклеточного вещества

5) расщепление липидов под действием триглицеридлипазы

6) частичный протеолиз апоЛП

7) этерификация холестерина

8) ресинтез ЛП из кетоновых тел и белков

11. "Пенистые клетки" образуются при накоплении липидов: (2)

1) в макрофагах

2) лимфоцитах

3) нейтрофилах

4) гладкомышечных клетках

5) эндотелиальных клетках

12. Макрофаги поглощают лП при участии: (3)

1) рецептора ЛПнП

2) "скавенджер"-рецептора

3) рецептора холестерина

4) рецептора лпонП

5) рецептора фосфолипидов

13. Основными компонентами фиброзной бляшки являются: (2)

1) макрофаги

2) В лимфоциты

3) Т лимфоциты

4) гладкомышечные клетки

5) фибробласты

6) тучные клетки

14. Атеросклероз характеризуется: (1)

1) накоплением ЛП в интиме артерий 
2) различными сочетаниями изменений интимы артерий в виде очагового отложения липидов, сложных соединений углеводов, элементов крови, компонентов соединительной ткани, солей кальция

3) изменениями интимы артерий в виде атеросклеротической бляшки, состоящей из липидов, гладкомышечных клеток, макрофагов, окруженных фиброзной капсулой

15. Типичная последовательность изменений при атерогенезе характеризуется: (1)

1) миграцией гладкомышечных клеток в очаг накопления липидов;

2) захватом ЛП макрофагами, превращение в "пенистые клетки";

3) выделением ростовых и хемотаксических факторов для гладкомышечных клеток;

4) повреждением эндотелия и накоплением ЛП в интиме артерий;

5) активацией синтеза коллагена и эластина гладкомышечными клетками;

6) образование фиброзной капсулы вокруг очага накопления липидов.

A: $\quad 4,3,1,2,5,6$

Б: $4,2,3,1,5,6$

B: $\quad 2,4,5,1,3,6$

16. Первичные атеросклеротические изменения артерий (липидные полоски) впервые появляются в возрасте: (1)

1) до 10 лет

2) 20-25 лет

3) 30-35 лет

4) 40-45 лет

5) после 50 лет

17. Наиболее частыми последствиями и осложнениями атеросклероза являются: (5)

1) аневризма аорты и/или других крупных артерий

2) недостаточность митрального клапана

3) облитерирующий эндартериит

4) инсульт мозга

5) тромбоз артерий

6) тромбоз вен

7) тромбоэмболия

8) ишемическая болезнь сердца

18. Факторами риска развития атеросклероза служат: (5)

1) гипоинсулинизм

2) гиперлипидемия

3) ожирение

4) артериальная гипертензия

5) гипокоагуляция

6) тромбоцитопения

7) табакокурение

8) образование антител к тромбоцитам

19. Число адипоцитов увеличивается: (1)

1) при гипертрофическом типе ожирения

2) гиперпластическом типе ожирения

20. Ожирению печени препятствуют: (3)

1) липокаин

2) метионин

3) витамин E

4) холин

5) биотин

6) соли желчных кислот
21. Верно то, что: (2)

1) андроидное ожирение является более значительным фактором риска атеросклероза, чем гиноидное

2) гиноидное ожирение является более значительным фактором риска атеросклероза, чем андроидное

3) висцеральное ожирение является более значительным фактором риска атеросклероза, чем субкутанное

4) субкутанное ожирение является более значительным фактором риска атеросклероза, чем висцеральное

22. Холестериновый коэффициент атерогенности свидетельствует о значительном риске развития атеросклероза, когда он превышает: (1)

1) 1

2) 2

3) 4

4) 3

(x) - число правильных ответов

\section{СИТУАЦИОННЫЕ ЗАДАЧИ}

\section{ЗАДАЧА 1}

В клинику обратилась пациентка Ж. в возрасте 18 лет с жалобами на одышку, усиливающуюся в ночное время, вследствие чего у нее нарушился сон. При осмотре: рост 162 см, вес 78 кг, акроцианоз, отмечается гипертрихоз на лице, ортопноэ (усиление одышки в положении лежа), артериальное давление 155/90 мм рт. ст, пастозность голеней, при выполнении ультразвукового исследования органов брюшной полости обнаружен гастроптоз, гепатомегалия и признаки жировой дистрофии печени, конкременты в желчном пузыре. При проведении спирографии - уменьшение жизненной емкости легких за счет резервной емкости легких. На электрокардиограмме - признаки перегрузки и гипертрофии миокарда правого желудочка сердца.

\section{вопРОсы}

1. Какие формы патологии имеются у Ж.?

2. С чем связано увеличение массы тела Ж.? Можно ли говорить о наличии у нее ожирения?

3. Какие дополнительные сведения необходимы Вам для уточнения состояния пациентки?

4. Каковы принципы и методы лечения состояний, подобных выявленным у Ж.? Назовите и охарактеризуйте их.

\section{ЗАДАЧА 2}

Пациент К., 18 лет, в течение 5 лет болен хроническим диффузным гломерулонефритом. В последние недели появились ноющие боли в сердце, сердцебиение, выраженные отеки, особенно нижних конечностей. Анализ мочи: суточный диурез 1100 мл, плотность 1,042, белок 3,3\%. Микроскопия осадка мочи: зернистые и восковидные цилиндры в большом количестве. Артериальное давление 170/95 мм рт. ст. Анализ крови: остаточный азот 70 мг\%, общий белок 4,8 г\%, альбумины 1,5 г\%, глобулины 2,8 г\%, гиперлипидемия, гипернатриемия.

\section{ВОПРОсы}

1. О развитии каких форм патологии свидетельствуют симптомы, имеющиеся у К.?

2. Какие виды нарушения липидного обмена могут при этом возникать? Каково их происхождение?

3. Каковы возможные последствия гиперлипидемии при условии ее длительного течения?

4. Имеются ли у К. признаки почечной недостаточности? Уремии? Аргументируйте Ваши заключения. 


\section{ВАРИАНТЫ ПРАВИЛЬНЫХ ОТВЕТОВ К КОНТРОЛЬНО-ИЗМЕРИТЕЛЬНЫМ МАТЕРИАЛАМ ЛЕКЦИИ}

ПРАВИЛЬНЫЕ ОТВЕТЫ НА ТЕСТОВЫЕ ЗАДАНИЯ

\author{
$1-1,2,4,5$ \\ $3-1,4,5,7$ \\ $5-1,3,4$ \\ $7-1,2,4$ \\ $9-1,2,5$ \\ $11-1,4$ \\ $13-1,4$ \\ $15-5$ \\ $17-1,4,5,7,8$ \\ $19-2$ \\ $21-1,3$
}

\section{ВАРИАНТЫ ПРАВИЛЬНЫХ ОТВЕТОВ НА ВОПРОСЫ К СИТУАЦИОННЫМ ЗАДАЧАМ ЗАДАЧА 1}

1. У Ж. имеется: артериальная гипертензия, синдром ночного апноэ, синдром поликистозных яичников, ожирение II ст., желчнокаменная болезнь, стеатоз печени. С учетом этого можно говорить о развитии у Ж. метаболического синдрома с характерными для него клиническими проявлениями (в т.ч. ишемической болезнью сердца, остеоартропатиями, сахарным диабетом II типа и др.).

2. У Ж. можно допустить наличие ожирения. Однако для этого необходимо доказать наличие (или отсутствие) висцерального (центрального) ожирения.

3. Для уточнения состояния Ж. необходимо выполнить компьютерную томографию органов брюшной полости на уровне III-IV, IV-V поясничных позвонков, измерить окружность талии и бедер, рассчитать отношение окружности талии к окружности бедер, выполнить (пер)оральный тест на толерантность к глюкозе, исследовать липидный спектр крови.

4. Лечение подобных состояний, получивших название "первичное управление метаболическим синдромом", заключается в пропаганде здорового образа жизни, включающей:

- обеспечение изменения соотношения образования энергии/энергозатрат (совершение работы + основной обмен) в сторону его уменьшения;

- умеренное сокращение калорий (5-10\% снижение массы тела за первый год);

- постепенное увеличение физической нагрузки;

- смену диетической структуры - снижение потребления насыщенных жиров и жиров в целом, рост потребления волокон, снижение потребления соли.

При недостаточной эффективности используют фармакотерапию или хирургическое вмешательство. Фармакотерапия направлена на коррекцию нарушения толерантности к глюкозе или лечение сахарного диабета, ожирения, артериальной гипертензии, дислипидемии.

\section{ЗАДАЧА 2}

1. У К. имеется: нефротический синдром, артериальная гипертензия, сердечная недостаточность, отек, гиперлипопротеинемия, гипопротеинемия.

2. У пациентов с такими формами патологии, как нефротический синдром и различные виды дислипопротеинемии, обычно развиваются гиперлипопротеинемии типа Ila (гипербеталипопротеинемия), IIb (гипербеталипопротеинемия), IV (гиперпребеталипопротеинемия) и V (гиперпребеталипопротеинемия, гиперхиломикронемия), повышенная секреция ЛПОНП и ЛПНП гепатоцитами, замедленное разрушение ими лПоНП и ЛПнП из-за сниженной активности липопротеинлипазы, повышенный синтез триглицеридов вследствие гиперлипацидемии.

3. Длительная гиперлипопротеинемия сопровождается увеличением образования модифицированных ЛП и развитием атеросклеротического повреждения сосудов.

4. У больного имеются признаки почечной недостаточности и уремии: повышение содержания остаточного азота в крови, гипопротеинемия (в связи с протеинурией), гиперлипидемия, гипернатриемия, гиперстенурия. 